\title{
The Effect of Nanomaterials on the Properties of Limestone Dust Green Concrete
}

\author{
Sajjad Monther Alsaedy \\ Department of Civil Engineering \\ College of Engineering \\ University of Baghdad \\ Baghdad, Iraq \\ s.naeem1901m@coeng.uobaghdad.edu.iq
}

\author{
Nada Aljalawi \\ Department of Civil Engineering \\ College of Engineering \\ University of Baghdad \\ Baghdad, Iraq \\ nada.aljalawi@coeng.uobaghdad.edu.iq
}

\begin{abstract}
Portland cement is considered the most involved product in environmental pollution. It is responsible for about $10 \%$ of global $\mathrm{CO}_{2}$ emissions [1]. Limestone dust is a by-product of limestone plants and it is produced in thousands of tons annually as waste material. To fulfill sustainability requirements, concrete production is recommended to reduce Portland cement usage with the use of alternative or waste materials. The production of sustainable high strength concrete by using nanomaterials is one of the aims of this study. Limestone dust in 12, 16, and $20 \%$ by weight of cement replaced cement in this study. The study was divided into two parts: the first was devoted to the investigation of the best percentage of replacement of waste lime. The second part of the study evaluated the performance of concrete when adding nanomaterials. Three percentages of cement replacement $0.5 \%, 1 \%$, and $1.5 \%$ with nano- $\mathrm{Al}_{2} \mathrm{O}_{3}$ were used. The most efficient content of hydrated lime used in this study which achieves sustainability and maintains the quality of concrete was $(16 \%)$. On the other hand, it was found that the best percentage of nano- $\mathrm{Al}_{2} \mathrm{O}_{3}$ as a partial replacement of cement is $1.5 \%$.
\end{abstract}

\section{Keywords-green concrete; limestone dust; nano $\mathrm{Al}_{2} \mathrm{O}_{3}$}

\section{INTRODUCTION}

Concrete is a widely used construction material, with an annual production that exceeds 10 billion tons [2]. Durability, fire resistance, water impermeability, cost efficiency, energy efficiency, and the ability to produce on-site are some of its advantages. However, cement manufacturing, which is the primary binder in concrete, necessitates a significant quantity of natural resources and energy. Approximately 1.5 tons of raw ingredients are required to produce one ton of cement [3]. The need to reduce $\mathrm{CO}_{2}$ emissions makes the search for alternative binders necessary. The necessity for more economical and environmentally friendly cement materials expanded the interest in other materials which can be used as substitutes to partially replace Ordinary Portland Cement (OPC) [4-6]. The cost of natural resources is increasing constantly, leading to the search for alternatives, such as recycled materials, rice husk ash, sawdust ash, tile powder, wood waste ash, silica fume, fly ash, coal bottom ash, limestone dust, Porcelinite, etc. [7-12]. Also, OPC is related to several diseases [13-17]. Limestone is the most prevalent type of calcium carbonate, often used in cement production. Calcium carbonate $\left(\mathrm{CaCO}_{3}\right)$, magnesium carbonate $\left(\mathrm{MgCO}_{3}\right)$, silica $\left(\mathrm{SiO}_{2}\right)$, alumina $\left(\mathrm{Al}_{2} \mathrm{O}_{3}\right)$, iron oxide $\left(\mathrm{Fe}_{2} \mathrm{O}_{3}\right)$, and sulphate $\left(\mathrm{SO}_{3}\right)$, are the principal components of limestone, with $\mathrm{CaCO}_{3}$ and $\mathrm{MgCO}_{3}$ being its major components [18]. Cements are primarily created by calcining a mixture of about $75 \%$ limestone and $25 \%$ clay to produce a calcium silicate clinker, which is then crushed and combined with a tiny amount of gypsum [19]. Nanomaterials are important due to properties such as the high surface to volume ratio. As the surface area per mass of a material increases, a larger amount of the material can come to contact with neighboring particles, therefore nanomaterials have high reactivity [20]. The inclusion of ultrafine nanomaterial particles fills the holes in the concrete microstructure. The nanopowder increases the surface area of the pozzolanic reaction, resulting in a more cementitious product $[21,22]$. In the present research, the effects of nanooxide (alumina) and limestone dust on concrete microstructure and mechanical properties are investigated.

\section{MATERIAL CHARACTERIZATION}

OPC produced by the Tassloja Cement Factory, confirming to Iraqi Specification No.5/2019 was used in this research [23]. Natural fine sand zone 2 (Table I), which is within the limits of the Iraqi Specification No. 45/1984 [24], was used as fine aggregates. Coarse aggregates with size of $5-14 \mathrm{~mm}$ were used to prepare concrete samples. The physical and chemical properties of fine and coarse aggregates are shown in Tables II and III respectively. All concrete samples were produced with the same water to cement ratio $(\mathrm{w} / \mathrm{c})$ of 0.3 . The concrete ingredients were mixed using 1:1.4:1.8 mixing ratio for cement, fine aggregates, and coarse aggregates respectively according to the British method for concrete mix design. Limestone dust was obtained from a limestone quarry in Karbala. It was finely ground in the form of dust, most of it passing the No.100 sieve. The chemical composition of the dust is given in Table IV. It was used to partially replace cement in concrete. Three different percentages $(12 \%, 16 \%$, and $20 \%$ ) by weight were used to replace cement. 
TABLE I. NATURAL FINE SAND GRADING

\begin{tabular}{|c|c|c|}
\hline $\begin{array}{c}\text { Sieve size } \\
(\mathbf{m m}) \\
10\end{array}$ & $\begin{array}{c}\text { Accumulative } \\
\text { passing (\%) } \\
100\end{array}$ & $\begin{array}{c}\text { Accumulative passing (\%) according to the } \\
\text { limits of I.Q.S No.45/1984 } \\
100\end{array}$ \\
\hline 4.75 & 100 & $90-100$ \\
\hline 2.36 & 88.7 & $75-100$ \\
\hline 1.18 & 66.9 & $55-90$ \\
\hline 0.6 & 51.8 & $35-59$ \\
\hline 0.3 & 18.8 & $8-30$ \\
\hline 0.15 & 3.4 & $0-10$ \\
\hline
\end{tabular}

TABLE II. PHYSICAL AND CHEMICAL PROPERTIES OF FINE AGGREGATES

\begin{tabular}{|c|c|c|}
\hline Properties of sand & Test results of sand & Limits of IQS No. 45/1984 \\
\hline Fineness modulus & 2.76 & - \\
\hline Specific gravity & 2.63 & - \\
\hline Absorption & $0.8 \%$ & - \\
\hline $\mathrm{SO}_{3}$ & $0.23 \%$ & $\leq 0.5 \%$ \\
\hline Dry rodded density & $1604 \mathrm{~kg} / \mathrm{m}^{3}$ & - \\
\hline
\end{tabular}

TABLE III. PHYSICAL AND CHEMICAL PROPERTIES OF COARSE AGGREGATES

\begin{tabular}{|c|c|c|}
\hline Properties of gravel & Test results of gravel & $\begin{array}{c}\text { Limits of IQS No. } \\
\mathbf{4 5} / \mathbf{1 9 8 4}\end{array}$ \\
\hline Specific gravity & 2.652 & - \\
\hline Absorption & $0.7 \%$ & - \\
\hline $\mathrm{SO}_{3}$ & $0.05 \%$ & $\leq 0.1 \%$ \\
\hline Dry rodded density & $1640 \mathrm{~kg} / \mathrm{m}^{3}$ & - \\
\hline
\end{tabular}

TABLE IV. CHEMICAL ANALYSIS OF LIMESTONE DUST

\begin{tabular}{|c|c|}
\hline Chemical composition & Constituent \% \\
\hline Silicon dioxide $\left(\mathrm{SiO}_{2}\right)$ & 5.15 \\
\hline Calcium oxide $(\mathrm{CAO})$ & 52.1 \\
\hline Aluminium oxide $\left(\mathrm{Al}_{2} \mathrm{O}_{3}\right)$ & 0.66 \\
\hline Ferric oxide $\left(\mathrm{Fe}_{2} \mathrm{O}_{3}\right)$ & 0.08 \\
\hline Magnesium oxide $(\mathrm{MgO})$ & 0.51 \\
\hline Sulphur oxide $\left(\mathrm{SO}_{3}\right)$ & 0.0 \\
\hline Loss on ignition & 41.49 \\
\hline
\end{tabular}

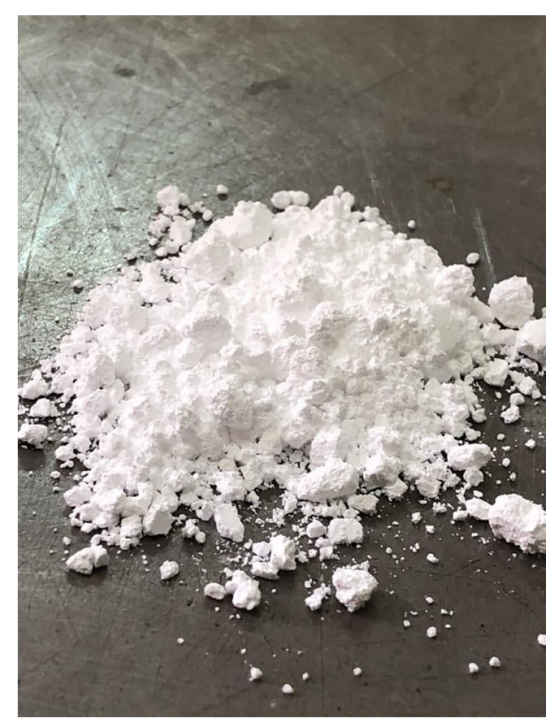

Fig. 1. Nano $\mathrm{Al}_{2} \mathrm{O}_{3}$ used in the research.

The nanomaterial $\mathrm{Al}_{2} \mathrm{O}_{3}$ shown in Figure 1 was used as the partial replacement of cement. It was purchased from Skyspring Nanomaterials Ltd and its physical analysis is shown in Table V. Three different percentages of $0.5,1$, and $1.5 \mathrm{wt} \%$ of cement were used.

TABLE V. PHYSICAL PROPERTIES OF NANO $\mathrm{Al}_{2} \mathrm{O}_{3}$

\begin{tabular}{|c|c|}
\hline Property & Specifications \\
\hline Appearance & Milky white \\
\hline Crystal structure and type & Alpha \\
\hline Purity $\%$ & 99 \\
\hline Form & Powder \\
\hline Density & $3.5-3.9 \mathrm{~g} / \mathrm{cm}^{3}$ \\
\hline
\end{tabular}

\section{EXPERIMENTAL PROGRAM}

The experimental part consisted of 7 concrete mixes as shown in Table VI (the concrete ingredients were mixed using 1:1.4:1.8 mixing ratio for cement, fine aggregates, and coarse aggregates respectively, according to the British method for concrete mix design).

TABLE VI. MIX DESIGN DETAILS FOR CONCRETE MIXES

\begin{tabular}{|c|c|cc|cc|}
\hline \multirow{2}{*}{$\begin{array}{c}\text { Mix } \\
\text { symbol }\end{array}$} & \multirow{2}{*}{ w/b } & $\begin{array}{c}\text { HRWRA } \\
\text { (lt/100kg } \\
\text { cement) }\end{array}$ & $\begin{array}{c}\text { Cement } \\
\mathbf{( k g / \mathbf { m } ^ { 3 } )}\end{array}$ & $\begin{array}{c}\text { Limestone } \\
\mathbf{d u s t} \\
\left(\mathbf{k g} / \mathbf{m}^{\mathbf{3}}\right)\end{array}$ & $\begin{array}{c}\text { Nano } \\
\mathbf{A l}_{\mathbf{2}} \mathbf{O}_{\mathbf{3}} \mathbf{( \% )}\end{array}$ \\
\cline { 1 - 3 } MR & & & 500 & 0 & 0 \\
\hline ML1 & & & 440 & 60 & 0 \\
\hline ML2 & \multirow{2}{*}{0.3} & 2.5 & 420 & 80 & 0 \\
\hline ML3 & & 400 & 100 & 0 \\
\hline MN1 & & & 417.9 & 80 & 0.5 \\
\hline MN2 & & & 415.8 & 80 & 1 \\
\hline MN3 & & & 413.7 & 80 & 1.5 \\
\hline
\end{tabular}

\section{SPECIMEN PREPARATION}

Specimens in the shape of cube, prism, and cylinder were prepared to test compressive strength, flexural strength, and splitting tensile strength respectively. The steel molds were cleaned and their internal surfaces were lubricated with oil to prevent adhesion with concrete after hardening. The molds were filled with concrete in layers, and each layer was compacted by a vibrating table according to ASTM C$192 /$ C192M [25], which is sufficient to remove any entrapped air. After compaction, the specimens were leveled by hand troweling, then left for 24 hours. The specimens were then removed from the molds, and were cured in water until the time of test. All specimens were cured in laboratory environment conditions according to ACI 308R-01 [26].

\section{RESUlts}

The tests performed on hardened concrete were the slump test, the compressive strength test, the flexural strength test, the splitting tensile strength test, and the SEM test.

\section{A. Workability (Slump Test)}

The workability of concrete mixes was measured directly after mixing, according to ASTM C143 [27]. The results are shown in Table VII.

\section{B. Compressive Strength Test}

The compressive strength of the concrete mixes was determined according to British Standard BS 12390-3:2019 [28] on $100 \times 100 \times 100 \mathrm{~mm}$ cubes. The cubes were tested as shown in Figure 2 at the age of 7, 28, and 90 days. The average 
result of three tested cubes was taken for each mix. The compressive strength for each cube was calculated as shown in (1):

$$
F_{c u}=P / A
$$

where $F_{c u}$ is the compressive strength (MPa), $A$ the face area of the cube $\left(\mathrm{mm}^{2}\right)$, and $P$ the compressive load at failure $(\mathrm{N})$. The results are shown in Table VIII.

TABLE VII. SLUMP TEST RESULTS

\begin{tabular}{|c|c|}
\hline Mix symbol & Slump (mm) \\
\hline MR & 102 \\
\hline ML1 & 116 \\
\hline ML2 & 122 \\
\hline ML3 & 125 \\
\hline MN1 & 117 \\
\hline MN2 & 111 \\
\hline MN3 & 107 \\
\hline
\end{tabular}

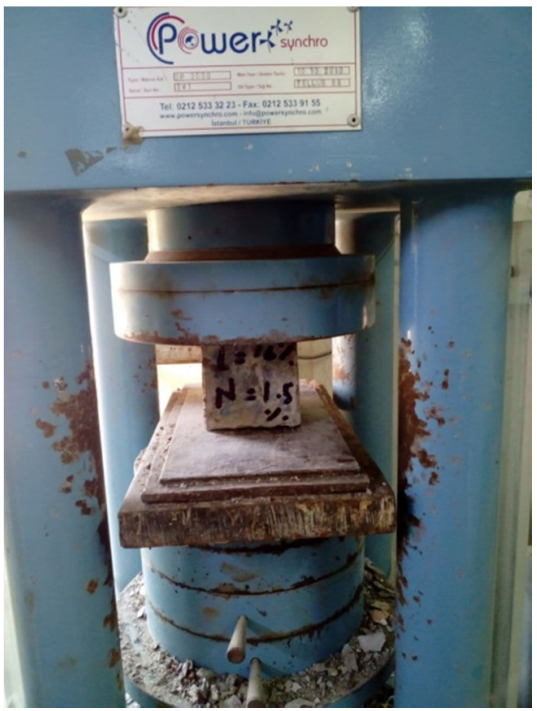

Fig. 2. Compressive strength test

\section{Flexural Strength Test}

Flexural strength was determined according to ASTM C 293-07 [29] by the center point method. The prism specimens with dimensions of $100 \times 100 \times 400 \mathrm{~mm}$ were simply supported with $300 \mathrm{~mm}$ span and were tested at the age of 7 and 28 days. The average of three prisms was taken for each mix. Modulus of rupture was calculated with:

$$
F_{r}=3 P L / 2 b d^{2}
$$

where $F_{r}$ is the flexural strength $(\mathrm{MPa}), P$ the maximum applied load indicated by the test machine $(\mathrm{N}), L$ the average length of the specimen $(\mathrm{mm}), b$ the average width of the specimen $(\mathrm{mm})$, and $d$ the average depth of the specimen $(\mathrm{mm})$. The results are shown in Table VIII.

\section{Splitting Tensile Strength Test}

Concrete cylindrical specimens with dimensions of $150 \times 300 \mathrm{~mm}$ were used in this test to determine the splitting tensile strength according to ASTM C 496-04 [30] using a compressive machine. In this test method, a diametric compressive force is applied along the side of a concrete cylindrical specimen until tensile failure occurs. The steel plate of the compressive machine is used to distribute uniformly the load applied along the length of the cylinder. The cylinders were tested at the age of 7 and 28 days, and the average of three cylinders was taken as the final result. Splitting tensile strength was calculated by:

$$
\tau=2 P / \pi L D
$$

where $\tau$ the splitting tensile strength (MPa), $P$ the maximum. applied load $(\mathrm{N}), L$ the length of the specimen $(\mathrm{mm})$, and $D$ its diameter $(\mathrm{mm})$. The results are shown in Table VIII.

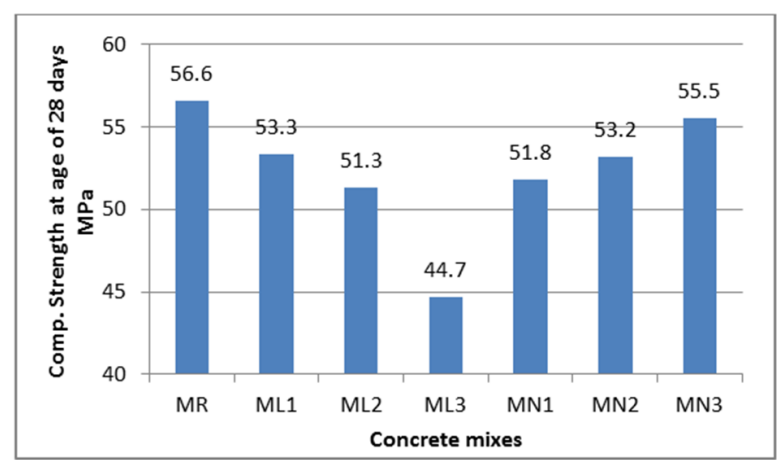

Fig. 3. Compressive strength for all concrete mixes at the age of 28 days.

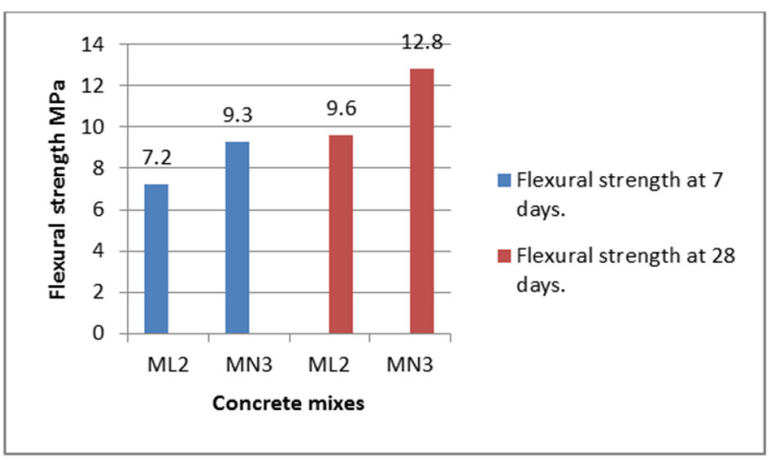

Fig. 4. Flexural strength for ML2 and MN3 mixes at 7 and 28 days.

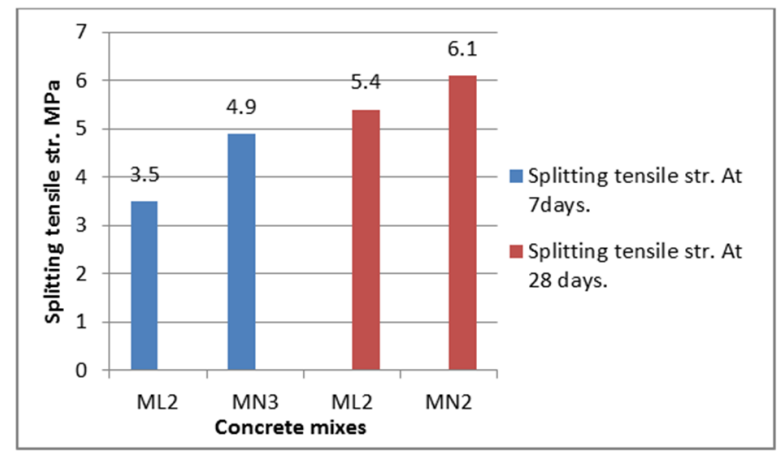

Fig. 5. Splitting tensile strength for ML2 and MN3 at 7 and 28 days

\section{E. Dry Density}

The specimens were tested according to the Iraqi Guide 274 [31]. The average result of three samples was calculated at 7 , 
28, and 90 days for each mix after picking the cubes out of the curing water and drying their surfaces with a cloth. Density $(\rho)$ is the mass of a unit volume of hardened concrete expressed in $\mathrm{kg} / \mathrm{m}^{3}$. The density was calculated from the specimen mass with volume of $100 \times 100 \times 100 \mathrm{~mm}$ obtained after air dry by:

$$
\rho=M / V
$$

where $\rho$ is the $\operatorname{density}\left(\mathrm{kg} / \mathrm{m}^{3}\right), M$ the mass of specimen at the time of test $(\mathrm{kg})$, and $V$ the volume of the specimen calculated from its dimensions $\left(\mathrm{m}^{3}\right)$. The results are shown in Table IX.

TABLE VIII. SUMMARY OF COMPRESSIVE, FLEXURAL, AND TENSILE STRENGTH TEST RESULTS

\begin{tabular}{|c|c|c|c|c|cc|c|}
\hline \multirow{2}{*}{$\begin{array}{c}\text { Mix } \\
\text { symbol }\end{array}$} & \multicolumn{3}{|c|}{$\begin{array}{c}\text { Compressive strength } \\
\text { (MPa) }\end{array}$} & \multicolumn{2}{c|}{$\begin{array}{c}\text { Flexural } \\
\text { strength (MPa) }\end{array}$} & $\begin{array}{c}\text { Splitting tensile } \\
\text { strength (MPa) }\end{array}$ \\
\cline { 2 - 9 } & 7 days & 28 days & 90 days & 7 days & 28 days & 7 days & 28 days \\
\hline MR & 43.8 & 56.6 & 68.5 & - & - & - & - \\
\hline ML1 & 40.6 & 53.3 & 66.0 & - & - & - & - \\
\hline ML2 & 39.1 & 51.3 & 63.6 & 6.2 & 8.6 & 3.5 & 5.4 \\
\hline ML3 & 34.2 & 44.7 & 60.1 & - & - & - & - \\
\hline MN1 & 40.4 & 51.8 & 64.9 & - & - & - & - \\
\hline MN2 & 44.0 & 53.2 & 65.8 & - & - & - & - \\
\hline MN3 & 46.1 & 55.5 & 69.0 & 8.3 & 11.8 & 4.9 & 6.1 \\
\hline
\end{tabular}

TABLE IX. DRY DENSITY RESULTS

\begin{tabular}{|c|c|c|c|}
\hline \multirow{2}{*}{$\begin{array}{c}\text { Mix } \\
\text { symbol }\end{array}$} & \multicolumn{3}{|c|}{ Dry density( $\mathbf{k g} / \mathbf{m}^{\mathbf{3}} \mathbf{)}$} \\
\cline { 2 - 4 } & 7 days & 28 days & 90 days \\
\hline MR & 2511 & 2525 & 2536 \\
\hline ML1 & 2452 & 2476 & 2484 \\
ML2 & 2449 & 2472 & 2481 \\
\hline ML3 & 2437 & 2459 & 2470 \\
\hline MN1 & 2523 & 2534 & 2541 \\
\hline MN2 & 2540 & 2548 & 2557 \\
\hline MN3 & 2556 & 2569 & 2580 \\
\hline
\end{tabular}

\section{F. Scanning Electron Microscopy (SEM)}

SEM was used to observe the products of nanomaterials. Figures 6 and 7 show the SEM results of a sample from the MLN concrete mix. For this observation, samples were taken from the cracked surface of the specimens of the concrete mixes. In Figures 6, 7 the samples prepared with nano $\mathrm{Al}_{2} \mathrm{O}_{3}$ show more density at C-S-H gel.

\section{G. Result Summary}

When adding limestone dust to the green concrete production, there was an improvement in workability and a slight decrease in the mechanical properties of concrete, but after adding nanomaterials, the properties begun to increase again, so green concrete containing waste material with high properties can be produced. The importance of this research lies in the possibility of replacing a good percentage of cement with waste material while maintaining the same properties. The results of this study are similar with the findings in [21, 32].

\section{CONCLUSIONS}

Based on the results obtained from the experimental investigation, the following conclusions can be drawn:

- Within certain ranges of strength and workability criteria, finely ground limestone dust can be recommended as a partial alternative for cement to produce green concrete.
- The dry density of concrete with limestone dust is always lower than that of normal concrete made with OPC only. When adding nano $\mathrm{Al}_{2} \mathrm{O}_{3}$, the dry density increases with the increase in nano $\mathrm{Al}_{2} \mathrm{O}_{3}$.

- From all the tested mixes, $16 \%$ dust by weight was found to be most satisfactory as it exhibits optimum compressive, tensile, and flexural strength, and a remarkable increase in workability.

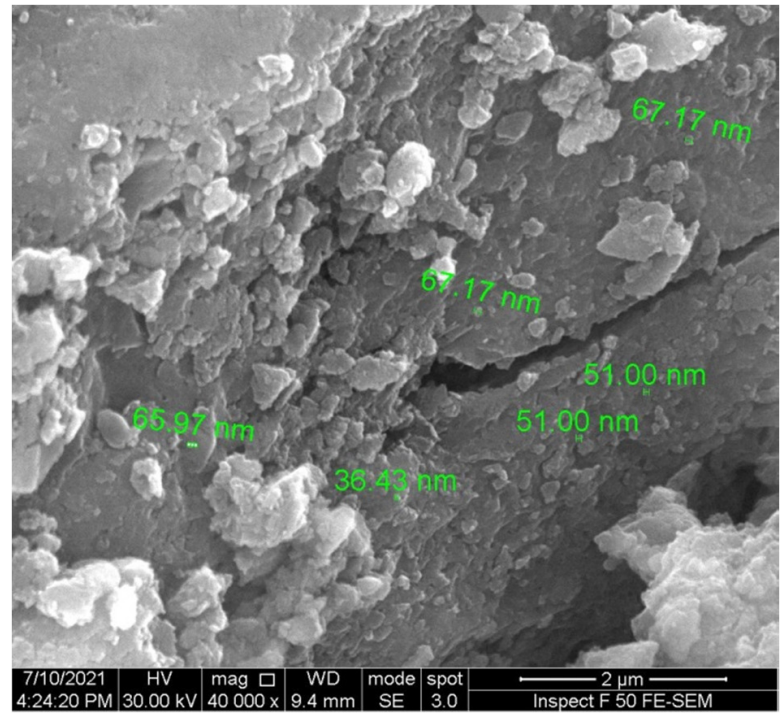

Fig. 6. SEM image of concrete hydrated for 28 days with $1.5 \%$ nanoalumina.

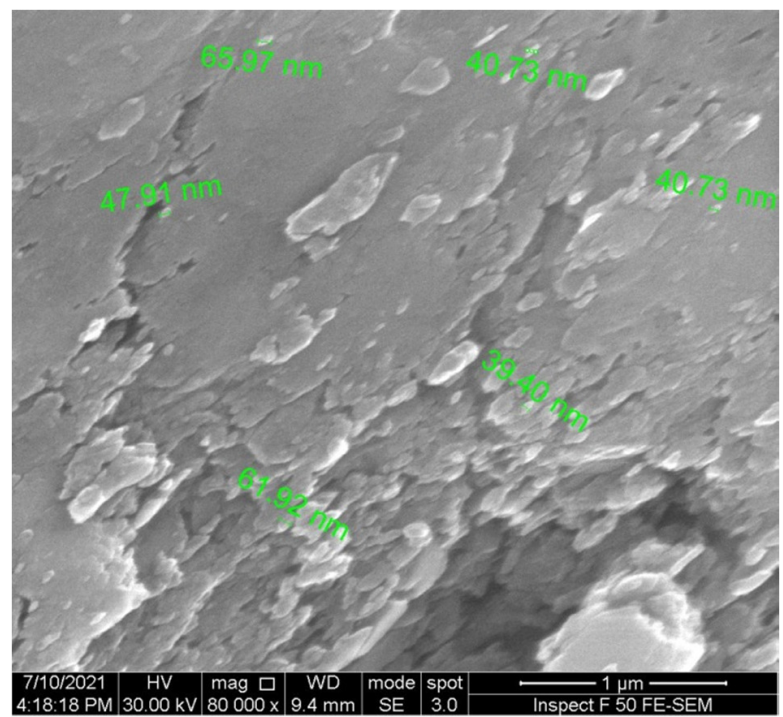

Fig. 7. SEM image of concrete hydrated for 28 days with $1.5 \%$ nanoalumina with different scale.

- The compressive strength result of samples with nano alumina showed that the combination of nano-particles and micro-particles of limestone dust increased the compressive strength of concrete samples compared with the compressive strength of concrete with only limestone dust. 
This observation indicates that nano alumina has a good filler effect and further distribution of the particles in the remaining voids lead to a more homogeneous concrete matrix which increases the compressive strength of the produced concrete.

- Homogeneity was found to be increased with nano particle addition. This was due to the smaller size of the particles leading to an improvement in the surface characteristics of concrete by smoothening the grain and closing the pores thus increasing concrete strength.

- The addition of nano-alumina with limestone dust to the concrete mixture improved concrete properties and allows the production of high strength green concrete.

\section{REFERENCES}

[1] M. J. Memon, A. A. Jhatial, A. Murtaza, M. S. Raza, and K. B. Phulpoto, "Production of eco-friendly concrete incorporating rice husk ash and polypropylene fibres," Environmental Science and Pollution Research, vol. 28, no. 29, pp. 39168-39184, Aug. 2021, https://doi.org/ 10.1007/s11356-021-13418-3.

[2] A. M. Neville, Properties of Concrete, 5th ed. Philadelphia,USA: TransAtlantic Publications, 2012.

[3] A. M. Rashad, "An exploratory study on high-volume fly ash concrete incorporating silica fume subjected to thermal loads," Journal of Cleaner Production, vol. 87, pp. 735-744, Jan. 2015, https://doi.org/ 10.1016/j.jclepro.2014.09.018.

[4] A. Goyal, A. M. Anwar, H. Kunio, and O. Hidehiko, "Properties of sugarcane bagasse ash and Its Potential as Cement-Pozzolana Binder," in Twelfth International Colloquium on Structural and Geotechnical Engineering, Dec. 2007, pp. 10-12.

[5] N. Bheel, A. Memon, S. Meghwar, A. Abro, and I. Shar, "Millet Husk Ash as Environmental Friendly Material in Cement Concrete," in 5th International Conference on Energy, Environment and Sustainable Development, Jamshoro, Pakistan, Nov. 2018.

[6] N. Bheel, S. Abbasi, S. Meghwar, and F. Shaikh, "Effect of Human hair as Fibers in Cement Concrete," in International Conference on Sustainable Development in Civil Engineering, Jamshoro, Pakistan, Nov. 2017.

[7] S. A. Mangi, N. Jamaluddin, M. H. Wan Ibrahim, N. Mohamad, and S. Sohu, "Utilization of Sawdust Ash as Cement Replacement for the Concrete Production: A Review," Engineering Science and Technology International Research Journal, vol. 1, no. 3, pp. 11-15, 2017.

[8] N. Bheel, R. A. Abbasi, S. Sohu, S. A. Abbasi, A. W. Abro, and Z. H. Shaikh, "Effect of Tile Powder Used as a Cementitious Material on the Mechanical Properties of Concrete," Engineering, Technology \& Applied Science Research, vol. 9, no. 5, pp. 4596-4599, Oct. 2019, https://doi.org/10.48084/etasr.2994.

[9] M. S. Raza, K. Rai, D. Kumar, and M. Ali, "Experimental Study of Physical, Fresh-State and Strength Parameters of Concrete incorporating Wood Waste Ash as a Cementitious Material," Journal of Materials and Engineering Structures, vol. 7, no. 2, pp. 267-276, Jul. 2020.

[10] M. Kepniak, P. Woyciechowski, P. Lukowski, J. Kuziak, and R. Kobylka, "The Durability of Concrete Modified by Waste Limestone Powder in the Chemically Aggressive Environment," Materials, vol. 12, no. 10, Jan. 2019, Art. no. 1693, https://doi.org/10.3390/ma12101693.

[11] S. A. Mangi et al., "A Review on Potential use of Coal Bottom Ash as a Supplementary Cementing Material in Sustainable Concrete Construction," International Journal of Integrated Engineering, vol. 10, no. 9, pp. 28-36, 2018

[12] Q. J.-A. Hachim and N. M. Fawzi, "The Effect of Different Types of Aggregate and Additives on the Properties of Self-Compacting Lightweight Concrete," Journal of Engineering, vol. 18, no. 8, pp. 875888,2012 .

[13] M. J. Memon, A. A. Jhatial, Z. A. Rid, T. A. Rind, and A. R. Sandhu, "Marble Powder As Fine Aggregates in Concrete," Engineering,
Technology \& Applied Science Research, vol. 9, no. 3, pp. 4105-4107, Jun. 2019, https://doi.org/10.48084/etasr.2698.

[14] N. Bheel, S. L. Meghwar, S. Sohu, A. R. Khoso, A. Kumar, and Z. H. Shaikh, "Experimental Study on Recycled Concrete Aggregates with Rice Husk Ash as Partial Cement Replacement," Civil Engineering Journal, vol. 4, no. 10, pp. 2305-2314, Oct. 2018, https://doi.org/ 10.28991/cej-03091160.

[15] N. Bheel, A. W. Abro, I. A. Shar, A. A. Dayo, S. Shaikh, and Z. H. Shaikh, "Use of Rice Husk Ash as Cementitious Material in Concrete," Engineering, Technology \& Applied Science Research, vol. 9, no. 3, pp. 4209-4212, Jun. 2019, https://doi.org/10.48084/etasr.2746.

[16] N. M. Fawzi and A. Y. E. AL-Awadi, "Enhancing Performance of SelfCompacting Concrete with Internal Curing Using Thermostone Chips," Journal of Engineering, vol. 23, no. 7, pp. 1-13, Jun. 2017.

[17] A. A. Jhatial, W. I. Goh, S. Sohu, S. A. Mangi, and A. K. Mastoi, "Preliminary Investigation of Thermal Behavior of Lightweight Foamed Concrete Incorporating Palm Oil Fuel Ash and Eggshell Powder," Periodica Polytechnica Civil Engineering, vol. 65, no. 1, pp. 168-180, 2021, https://doi.org/10.3311/PPci.16498.

[18] P. M. Harris, Limestone \& Dolomite: Mineral Resources Consultative Committee. London, UK: HMSO, 1982

[19] A. Dinku, "The Influence of Limestone Aggregates and Limestone Fillers on the Properties of Concrete," M.S. thesis, University of Leeds, Leeds, UK, 1991.

[20] P. van Broekhuizen, F. van Broekhuizen, R. Cornelissen, and L. Reijnders, "Use of nanomaterials in the European construction industry and some occupational health aspects thereof," Journal of Nanoparticle Research, vol. 13, no. 2, pp. 447-462, Feb. 2011, https://doi.org/10. 1007/s11051-010-0195-9.

[21] R. K. Mohammed, A. A. Abdel-Hamead, and F. M. Othman, "Effect of Nano-Alumina on Microstructure and Mechanical properties of Recycled Concrete," Journal of Engineering and Sustainable Development, vol. 22, no. 2 (Part-1), pp. 90-103, 2018.

[22] S. Hallad et al., "Effect of Multiwalled Carbon Nanotubes and Nano Aluminum Oxide On Flexural and Compressive Strength of Cement Composites," International Journal of Advance Research In Science And Engineering, vol. 3, no. 8, pp. 215-223, Aug. 2014.

[23] Iraqi Standard No. 5: Portland Cement. Baghdad, Iraq: Central Organizationfor Standardization and Quality Control, 2019.

[24] Iraqi Specifications No. 45 for Aggregates of Natural Resources used for Concrete and Construction. Baghdad, Iraq, 1984.

[25] ASTM C192/C192M-16a (2017), Standard Practice for Making and Curing Concrete Test Specimens in the Laboratory. West Conshohocken, PA, USA: ASTM International, 2017.

[26] ACI Committee 308, 308R-01: Guide to Curing Concrete. Technical Documents, 2001.

[27] ASTM C143/C143M-20(2020), Standard Test Method for Slump of Hydraulic-Cement Concrete. West Conshohocken, PA, USA: ASTM International, 2020.

[28] BS EN 12390-3(2019), Testing hardened concrete. Compressive strength of test specimens. London, UK: British Standards Institution, 2019.

[29] ASTM C293/C293M-16(2016), Standard Test Method for Flexural Strength of Concrete. West Conshohocken, PA, USA: ASTM International, 2016.

[30] ASTM C496/C496M-17(2017), Standard Test Method for Splitting Tensile Strength of Cylindrical Concrete Specimens. West Conshohocken, PA, USA: ASTM International, 2017.

[31] Iraqi Guide No. 274 Methods for determining the density of hardened concrete. Baghdad, Iraq: Central Organizationfor Standardization and Quality Control, 1992.

[32] H. Binici, H. Kaplan, and S. Yilmaz, "Influence of marble and limestone dusts as additives on some mechanical properties of concrete," Scientific Research and Essays, vol. 2, no. 9, pp. 372-379, Sep. 2007, https://doi.org/10.5897/SRE.9000594. 